\title{
Evaluation and revision of questionnaires for use among low-literacy immigrant Latinos
}

Karen T. D'Alonzo'

As more Spanish speaking immigrants participate in and become the focus of research studies, questions arise about the appropriateness of existing research tools. Questionnaires have often been adapted from English language instruments and tested among collegeeducated Hispanic-Americans. Little has been written regarding the testing and evaluation of research tools among less educated Latino immigrants. The purpose of this study was to evaluate and revise a battery of Spanish-language questionnaires for an intervention among immigrant Hispanic women. A three-step process was used to evaluate, adapt and test Spanish versions of the Self-Efficacy and Exercise Habits Survey, an abbreviated version of the Hispanic Stress Inventory-Immigrant version and the Latina Values Scale. The revised tools demonstrated acceptable validity and reliability. The adaptations improved the readability of the tools, resulting in a higher response rate, less missing data and fewer extreme responses. Psychometric limitations to the adaptation of Likert scales are discussed.

Descriptors: Psychometrics; Immigrant Health; Health Disparities.

\footnotetext{
${ }^{1}$ RN, Ph.D in Nursing, Assistant Professor, Rutgers, The State University of New Jersey, College of Nursing, New Jersey, USA. E-mail: kdalonzo@rutgers.edu.
}

Corresponding Author:

Karen T. D'Alonzo

Rutgers, The State University of New Jersey

College of Nursing

180 University Avenue, Rm. 226

Newark, NJ USA 07102

E-mail: kdalonzo@rutgers.edu 


\title{
Avaliação e revisão de questionários para uso entre imigrantes latinos com baixos níveis de alfabetização
}

À medida que número maior de imigrantes de língua espanhola participa de pesquisas, surgem questões relacionadas à adequação de instrumentos já existentes. Questionários, em versões inglesas, são frequentemente adaptados e testados com americanos de origem hispânica com nível superior. Pouco tem sido escrito sobre testes e avaliação desses instrumentos de pesquisa entre imigrantes com níveis mais baixos de escolaridade. 0 objetivo deste estudo foi avaliar e revisar uma bateria de questionários para intervenção com mulheres imigrantes hispânicas. Utilizou-se um processo de três etapas para avaliar, adaptar e testar as versões espanholas dos instrumentos Self-Efficacy and Exercise Habits Survey, versão abreviada para imigrantes do Hispanic Stress Inventory e o Latina Values Scale. Os instrumentos revisados demonstraram validade e confiabilidade aceitáveis. As adaptações melhoraram a compreensão dos instrumentos, aumentando a taxa de respostas e reduzindo dados omissos e respostas extremas. Limitações psicométricas da adaptação de escalas do tipo Likert também são abordadas.

Descritores: Psicométricas; Saúde de Imigrantes; Disparidades de Saúde.

\section{Evaluación y revisión de cuestionarios para uso en inmigrantes Latinos con bajo grado de alfabetización}

\begin{abstract}
En la medida en que un número mayor de inmigrantes de lengua española participa de investigaciones, surgen cuestiones relacionadas a la adecuación de instrumentos ya existentes. Cuestionarios, en versiones inglesas, son frecuentemente adaptados y comprobados con americanos de origen hispana con nivel superior. Poco ha sido escrito sobre pruebas y evaluación de esos instrumentos de investigación entre inmigrantes con grados más bajos de escolaridad. El objetivo de este estudio fue evaluar y revisar una batería de cuestionarios para intervención con mujeres inmigrantes hispanas. Se utilizó un proceso de tres etapas para evaluar, adaptar y comprobar las versiones españolas de los instrumentos Self-Efficacy and Exercise Habits Survey, versión abreviada para inmigrantes del Hispanic Stress Inventory y Latina Values Scale. Los instrumentos revisados demostraron validad y confiabilidad aceptables. Las adaptaciones mejoraron la comprensión de los instrumentos, aumentando la tasa de respuestas y reduciendo datos omisos y respuestas extremas. Las limitaciones psicométricas de la adaptación de escalas del tipo Likert también son abordadas.
\end{abstract}

Descriptores: Psicometría; La Salud Inmigrante; Disparidades de Salud.

\section{Introduction}

Latinos, or persons of Hispanic descent, comprise nearly $16 \%$ of the total United States (U.S.) population and are the fastest growing minority group in the US ${ }^{(1)}$. Approximately $40 \%$ of the over 45 million Latinos living in the US are foreign born and close to $75 \%$ of firstgeneration Latino immigrants speak Spanish most of the time. Furthermore, many Latino immigrants have lower levels of formal education and are unlikely to be familiar with research terminology. As more Spanish speaking immigrants participate in and become the focus of research studies in the US, questions arise about the appropriateness of existing research tools. Questionnaires designed for use among Latinos in the U.S. have often been translated from English and 
tested among second and third generation collegeeducated Hispanic-Americans. This approach assumes that persons of Hispanic ancestry are a homogenous, well educated group. Little has been written regarding the evaluation and testing of research tools among less educated Latino immigrants, particularly those who are less familiar with the research process.

\section{Methodological issues}

For some time, researchers have reported procedural difficulties in conducting research among Hispanic populations ${ }^{(2-3)}$. In addition to translation issues, there are a number of culturally-based methodological concerns for non-Hispanic researchers working with Latinos(4). Most frequently cited is a cultural bias associated with the use of Likert scales among Latinos ${ }^{(2)}$. Likert scales are popular in the social sciences, but low-literacy immigrant Latinos may have a poor understanding of the graded response format ${ }^{(3,5)}$. Specific response trends include social desirability responses(6), extreme response sets (excessive use of the endpoints of the scale) $)^{(7)}$ and missing data(8). Lastly, population-related extraneous variables may affect Latinos' responses to Likert scales, including age, level of education, acculturation and country of origin( $(2,3,7)$. Younger adults with more years of education and higher acculturation scores are less likely to report difficulties completing Likert scales(3). Historically, there has been little agreement among researchers regarding the most appropriate way to handle these methodological dilemmas ${ }^{(4,9)}$.

Purpose. The purpose of this study was to evaluate and revise a battery of Spanish-language questionnaires for an intervention among immigrant Hispanic women. The study consisted of three phases: Phase 1-Assessment of existing instruments; Phase 2-Revision of instruments and Phase 3-Preliminary assessment of the psychometric properties of the revised instruments. In Phases 1 and 2, the primary investigator was interested in assessing the appropriateness of the instrument response format, evidence of social desirability issues, extreme response styles, missing data and time needed for completion. Phase 3 focused on pilot testing the revisions and assessing the psychometric properties of the adapted instruments.

\section{Methods}

Phase 1-Assessment of existing instruments: A purposive sample of 13 females was recruited from a group of immigrant Latinas attending a promotora (community health worker) training program in New Jersey. The descriptive statistics for the subjects in Phases 1, 2 and 3 are presented in Table 1.

Data collection measures: (1) Self-Efficacy and Exercise Habits Survey ${ }^{(10)}$ (SEHS); (2) Latina Values Scale (LVS) ${ }^{(11)}$ and (3) Abbreviated version of the Hispanic Stress Inventory-Immigrant (HSI-I) ${ }^{(12)}$. The SEHS and the HSI-I had previously been translated into Spanish with good validity and reliability among U.S. Spanish speaking populations. A Spanish version of the LVS was not available during Phase 1 , so the author and three bi-lingual community consultants translated the tool into Spanish and then back- translated it into English. The English and Spanish versions of the questionnaires were compared and differences in terms and conceptual accuracies were resolved.

Self-Efficacy and Exercise Habits Survey ${ }^{(10):}$ The SEHS measures self-efficacy for exercise in relationship to two factors; "Making time for exercise" and "Resisting relapse". Alpha coefficients for the SEHS have been reported at .83 and .85 , with a test- retest reliability of .78. Both the English and Spanish versions of the SEHS have a six-point Likert scale; choices 1 and 2 correspond to "I am sure that I cannot" ("Estoy seguro que no puedo"), choices 3 and 4 represent "Perhaps I can" ("Quizas sí puedo"), while choices 5 and 6 correspond to "I am sure that I can" ("Estoy seguro que puedo"). The English version, developed among college students, contains 12 items, with a possible range of 12-72. The 15-item Spanish version was developed among community-dwelling adults and has a possible range of $15-90^{(13)}$. Higher scores are associated with a greater degree of exercise self-efficacy. 
Table 1 - Characteristics of the sample

\begin{tabular}{|c|c|c|c|}
\hline Description & Group $1(n=13)$ & Group $2(n=6)$ & Group $3(n=81)$ \\
\hline Mean age-years (SD) & $39.8(11.76)$ & $31.5(7.71)$ & $29.8(7.92)$ \\
\hline Mean number of years living in the US (SD) & $9.23(5.10)$ & $8.67(2.73)$ & $10.36(6.78)$ \\
\hline \multirow[t]{4}{*}{ Country of origin } & Mexico $(31 \%)$ & Mexico $(100 \%)$ & Mexico $(76 \%)$ \\
\hline & Honduras (25\%) & & Guatemala (4 \%) \\
\hline & Peru $(25 \%)$ & & $\begin{array}{c}\text { Others: Nicaragua, El Salvador, } \\
\text { Ecuador, Columbia }\end{array}$ \\
\hline & $\begin{array}{l}\text { Others: Puerto Rico, Ecuador, } \\
\text { Dominican Republic, Columbia }\end{array}$ & & \\
\hline Mean years of education (SD) & $10.33(2.87)$ & $9.17(2.86)$ & $9.04(1.86)$ \\
\hline \multicolumn{4}{|l|}{ Family income- } \\
\hline Less than $\$ 21,000 / y r$ & $31 \%$ & $50 \%$ & $26 \%$ \\
\hline$\$ 21,000-\$ 35,000 / y r$ & $23 \%$ & $17 \%$ & $5 \%$ \\
\hline$\$ 35,000-\$ 50,000 / y r$ & $15 \%$ & $0 \%$ & $6 \%$ \\
\hline Don't know & $31 \%$ & $33 \%$ & $36 \%$ \\
\hline
\end{tabular}

Latina Values Scale (LVS)(11): The 31-item two-stage Likert scale tool was developed among young Hispanic women in the US to measure beliefs about marianismo, traditional roles assigned to women in Hispanic culture. The LVS has demonstrated an inter-item reliability of .87. A significant inverse correlation ( $r=-.65, p=.01)$ was noted between scores from the LVS and those reported from a measure of assertiveness. Exploratory factor analysis (EFA) revealed three subscales: Responsibility, Assertion and Satisfaction. The "main scale" of the original English version is a six-point Likert scale, with the responses ranging from 1 - "I totally disagree" to 6"I totally agree". Scores in the main scale range from 31-186. Higher scores are associated with stronger marianismo beliefs. The "Satisfaction" scale contains 31 items, which correspond to the items in the main scale. For each question, the subject is asked, "How satisfied are you of your response?" The subject then chooses one of four anchors, ranging from 1- "I am very dissatisfied" to 4- "I am very satisfied." Scores on the satisfaction scale range from 31-124. High scores indicate the subject is very comfortable with her responses. A draft of a Spanish version of the tool was created as previously described.

Abbreviated version of the Hispanic Stress Inventory-Immigrant version (HSI-I)(12): The 17 itemtool was developed for immigrant Latinos. The five subscales deal with occupational or economic stress, parental stress, marital stress, immigration stress and family/culture stress. Internal consistencies across all subscales ranged from .68 to .83 . Convergent validity of the revised tool is supported with moderately positive relations through self-report measures of depression, anxiety, and anger mood levels. Respondents are asked to answer "Yes" or "No" to whether or not they have experienced a series of acculturation-related stressors in the past three months. If the answer is "yes", the subject is then instructed to indicate (on a scale of 1-5) how worried or tense the situation made them feel. A rating of one means the subject felt "Not at all worried/ tense" ("Nada preocupada(0)/tensa(0)") while a score of five indicates the subject felt "Extremely worried/ tense" ("Muy preocupada (0)/tensa(o)"). Scores on the HSI-I range from 17-85. Higher scores correspond to higher levels of subject anxiety.

Procedure: Following study explanation and informed consent, each of the women received a packet containing the questionnaires in random order. Subjects were instructed to answer the questions, spot the need for grammatical changes and identify any questions felt to be ambiguous or overly sensitive. Three bi-lingual research assistants aided women who requested clarification or who wished to have the questions read to them. Data were managed and demographic and psychometric analyses performed using SPSS version 16.0 for Windows (SPSS Inc. Chicago. III).

\section{Results}

Only eight of the 13 women were able to complete the questionnaires within one hour. Literacy level and number of years of education were prominent factors in 
completion of the questionnaires. The four subjects who had less than six years of formal education were most likely to omit multiple items. Six of the women noted difficulty in responding questions containing double negatives. Validity and reliability were not assessed due to the small sample size and the preponderance of missing data.

All of the women voiced displeasure with the Likert format. Half of the questionnaires showed evidence of the subjects' preference for extreme responses. Likewise, half of the group favored choices which avoided putting themselves in an unfavorable light (social desirability responses) or simply answered all of the questions with the same response (halo effect). The four completed packets contained significant amounts of missing data. For the SEHS, only four questionnaires were completed in their entirety. All contained a large number of positively skewed extreme responses to situations where exercising might be difficult ("I am sure that I can") ("Estoy seguro que si puedo'). Hence, the total scores for the SEHS were quite high (mean=41.5, $S D=2.4$ ), although none of the women were regular exercisers. The LVS was the longest instrument and contained some questions of a sexual nature which the women considered "too personal" to answer. Many of the subjects did not answer the second half of each question (Satisfaction subscale), which was a crucial component of the questionnaire. For those women who did respond, many later indicated they understood the phrase, "How satisfied are you of your response?" ("¿Cuán satisfecho está Usted con su respuesta?") to mean "How sure are you of your response?" ("¿Cuán seguro está Usted con su respuesta?"). Rather than appear indecisive, the majority of the women answered, "I am very satisfied"("Estoy muy satisfecho") without fully understanding the nature of the question. In the HSI-I, more than one-half of the women omitted the second half of each question and 3 of the questionnaires contained responses with strong halo effects.

Phase 2 - Revision of instruments: Prior to revisions, the primary investigator met with two bilingual community consultants and an experienced Latino researcher to discuss the difficulties encountered during the assessment of the questionnaires. Based upon the findings from Phase 1, the following changes were suggested and subsequently implemented: 1) Likert scales were collapsed into 3 choices; Yes/ No/I don't know, or I'm not sure; 2) a set of simple instructions, sample questions and responses were added to each questionnaire; 3) all of the tools were administered in the same order, beginning with the simplest tool first and ending with the longest and/ or one with the most sensitive questions; 4) local community women were trained as community research assistants (CRAs) to allow for a 2:1 ratio of subjects/assistants; 5) child care was provided during data collection; 6) scales were all written in the same direction; 7) tools were rewritten in a larger font with more "white space" around each question and 8) the LVS was replaced with The Latina Values ScaleRevised (LVS-R) ${ }^{(14)}$, a 28-item Spanish language version developed for young to middle-aged Latinas. In the LVS-R, the Satisfaction scale was replaced by the Conflict Scale and the second part of each question was rewritten as: "Has your response to this question caused problems or conflicts in your life?" ( $¿$ La respuesta a esta pregunta ha causado problemas o conflictos en su vida?). Study participants felt that this phrase better reflected the intent of the questionnaire. Cronbach's alpha for the LVS-R was .94 and .95 for the Conflict scale. In addition to the Conflict Scale, EFA of the LVS- $\mathrm{R}^{(14)}$ revealed six other factors: SelfSacrifice, Assertion, Guilt, Self-Blame, Putting Others First and Responsibility. The presence of seven factors in the LVS-R as opposed to only three factors in the LVS demonstrates the complexity of the concept of marianismo ${ }^{(14)}$. All of the revised tools were adapted to assure a sixth grade reading level in Spanish. Once permission was obtained from the authors, the revised tools were reviewed for face validity and cultural appropriateness by community consultants prior to administration to six promotoras. Characteristics of this sample are described in Table 1.

Results: All six participants completed the full battery of questionnaires. Mean completion time was 35 minutes, with all women answering close to $100 \%$ of the questions. Psychometric testing was not performed due to the small number of subjects.

Phase 3- Psychometric properties of the revised instruments: The revised tools were administered to 81 immigrant Hispanic women, ages 18-55 yrs., who participated in the Physical Activity Intervention for Latinas (PAIL) Study (manuscript in progress). The promotoras assisted subjects by reading/clarifying the meaning of selected questions and checking to see that all questions were answered. Mean completion time for the set of tools was 40 minutes, with less than two percent of missing data for all of the women. 
Psychometrics: Reliability of the revised tools was assessed through corrected item - total correlations and the internal consistency of each tool and adapted subscales. Construct validity was assessed through CFA, carried out on each revised tool through principal axis extraction with Varimax rotation ${ }^{(15)}$. Prior to CFA, the assumptions for factor analysis were tested and verified. Bartlett's Test of Sphericity, which measures the strength of the relationship among variables, and the Kaiser-MeyerOlkin (KMO) measure of sampling accuracy were used to assess the factorability of the correlation matrix ${ }^{(15)}$. A priori theory, the original tools and eigenvalues (factors with eigenvalues of less than 1.0 were excluded) guided factor extraction. Items with a factor loading greater than .32 were retained(15). A minimum of a .20 difference between an item's loading on theoretically aligned and opposed factors was recommended. Scree plots were used to corroborate decisions regarding factor extraction. The results of the psychometric analysis are presented in Tables 2, 3, and 4.

Table 2 - Factor loadings for Confirmatory Factor Analysis with Varimax Rotation of the Self-Efficacy for Exercise Habits Survey $(n=81)$

\begin{tabular}{|c|c|c|c|}
\hline Items & $\begin{array}{l}\text { Making time } \\
\text { for exercise }\end{array}$ & $\begin{array}{l}\text { Resisting } \\
\text { relapse }\end{array}$ & Communality \\
\hline $\begin{array}{l}\text { Ask my neighbors or friends to walk with me regularly. (Pedirle a sus vecinos o amigos de ir a caminar } \\
\text { con Ud. regularmente) }\end{array}$ & .69 & -.50 & .85 \\
\hline Ask my friends to exercise with me (Pedirle a sus amigos que hagan ejercicios con Ud.) & .48 & .27 & .63 \\
\hline Exercise with my family (Hacer ejercicios con su familia) & .58 & .24 & .67 \\
\hline $\begin{array}{l}\text { Stick to an exercise program even when emergencies arise at work (Seguir con su programa de } \\
\text { ejercicios aunque tenga demasiadas exigencias en el trabajo) }\end{array}$ & .65 & .06 & .82 \\
\hline $\begin{array}{l}\text { Stick to an exercise program even when social obligations take up much time (Seguir con su programa } \\
\text { de ejercicios aunque tenga obligaciones sociales que le toman mucho tiempo) }\end{array}$ & .71 & .25 & .71 \\
\hline $\begin{array}{l}\text { Begin a program of exercise after a break (such as Christmas or when it rains) (Empezar su programa } \\
\text { de ejercicios de después de una interrupción (como la Navidad o cuándo llueve)) }\end{array}$ & .58 & .33 & .78 \\
\hline $\begin{array}{l}\text { Set aside time to exercise for } 30 \text { minutes, three times a week. (Apartar tiempo para un programa de } \\
\text { ejercicio, por lo menos } 30 \text { minutos tres veces par semana) }\end{array}$ & .61 & .24 & .78 \\
\hline $\begin{array}{l}\text { Change my mealtime to make it more convenient to exercise (Cambiar su horario de comer para hacer } \\
\text { más conveniente el ejercicio) }\end{array}$ & .18 & .50 & .52 \\
\hline Wake up earlier to exercise (Levantarse mas temprano para hacer ejercicios) & .13 & .55 & .65 \\
\hline Set aside time for physical activity (Planear el ejercicio dentro su horario) & .18 & .57 & .47 \\
\hline Walk instead of driving short distances (Caminar en vez de manejar distancias cortas) & .34 & .42 & .71 \\
\hline Attend a party only after exercising (Ir a una fiesta solo después de haber hecho sus ejercicios) & .31 & .57 & .33 \\
\hline Exercise during my lunch hour (Hacer ejercicios durante la hora de comida) & -.08 & .60 & .63 \\
\hline $\begin{array}{l}\text { Stick to an exercise program when work is demanding and I am tired. (Seguir con su programa de } \\
\text { ejercicios después de un día de trabajo largo y cansado) }\end{array}$ & .43 & .62 & .71 \\
\hline Exercise when I feel depressed (Hacer sus ejercicios aunque se sienta deprimido) & .34 & .52 & .41 \\
\hline Eigenvalue & 4.6 & 1.7 & \\
\hline Percentage of variance explained & 30.7 & 11.5 & \\
\hline
\end{tabular}

Table 3 - Factor loadings for Confirmatory Factor Analysis with Varimax Rotation of the Latina Values Scale Revised (LVSR) $(n=81)$

\begin{tabular}{|c|c|c|c|c|c|c|c|c|}
\hline Items & Conflict & $\begin{array}{c}\text { Self- } \\
\text { sacrifice }\end{array}$ & Assertion & Guilt & $\begin{array}{l}\text { Self- } \\
\text { blame }\end{array}$ & $\begin{array}{l}\text { Putting } \\
\text { others first }\end{array}$ & Responsibility & Communality \\
\hline $\begin{array}{l}\text { I find myself doing things for others that I } \\
\text { would rather not do (Me encuentro a mi } \\
\text { misma haciendo cosas para otros que } \\
\text { preferiría no hacer) }\end{array}$ & .73 & .13 & .01 & .15 & .01 & .16 & .03 & .59 \\
\hline $\begin{array}{l}\text { I feel proud when others praise me for the } \\
\text { sacrifices I have made (Me siento orgullosa } \\
\text { cuándo otros me halagan por los sacrificios } \\
\text { que he hecho) }\end{array}$ & .52 & .26 & .41 & .32 & .23 & .08 & -.12 & .69 \\
\hline $\begin{array}{l}\text { I often take on responsibilities with my } \\
\text { family that l'd rather not take, because } \\
\text { it makes me feel like a better person ( } A \\
\text { menudo tomo responsabilidades familiars } \\
\text { que preferiria no tomar, porque me hace } \\
\text { sentir una mejor persona) }\end{array}$ & .66 & .09 & .18 & .02 & .34 & -.09 & -.05 & .60 \\
\hline
\end{tabular}


Table 3 - (continuation)

\begin{tabular}{|c|c|c|c|c|c|c|c|c|}
\hline Items & Conflict & $\begin{array}{l}\text { Self- } \\
\text { sacrifice }\end{array}$ & Assertion & Guilt & $\begin{array}{l}\text { Self- } \\
\text { blame }\end{array}$ & $\begin{array}{l}\text { Putting } \\
\text { others first }\end{array}$ & Responsibility & Communality \\
\hline $\begin{array}{l}\text { I often find myself doing things that will } \\
\text { make my family happy even when I know } \\
\text { it's not what I want to do (Yo a menudo me } \\
\text { encuentro haciendo cosas que hacen feliz } \\
\text { a mi familia, aún cuando se no es lo que } \\
\text { quiero hacer). }\end{array}$ & .75 & .03 & -.01 & .01 & .09 & -.03 & .16 & .60 \\
\hline $\begin{array}{l}\text { Being seen as a "good person" by others } \\
\text { is very important to me (Ser visto como } \\
\text { una "buena" persona por otros es muy } \\
\text { importante para mí) }\end{array}$ & .03 & .89 & -.02 & .02 & .06 & .04 & .01 & .80 \\
\hline $\begin{array}{l}\text { I am relieved that sacrificing myself for } \\
\text { others is eventually rewarded (Creo que mí } \\
\text { sacrificios podría ser recompensado algún } \\
\text { día) }\end{array}$ & .13 & .83 & .09 & .11 & .16 & .08 & .25 & .82 \\
\hline $\begin{array}{l}\text { I consider my family a great source of } \\
\text { support (Considero mi familia una gran } \\
\text { fuente de apoyo) }\end{array}$ & .10 & .07 & .83 & .11 & .08 & .12 & -.01 & .74 \\
\hline $\begin{array}{l}\text { Family is important to me (La familia es muy } \\
\text { importante para mí.) }\end{array}$ & .23 & .01 & .79 & .12 & .01 & .04 & .05 & .72 \\
\hline $\begin{array}{l}\text { I often take on responsibilities having } \\
\text { to do with my family (A menudo tomo } \\
\text { responsabilidades familiares). }\end{array}$ & .34 & .24 & .17 & .46 & -.31 & .26 & -.47 & .81 \\
\hline $\begin{array}{l}\text { I have difficulty expressing my anger (Tengo } \\
\text { dificultad expresando mi enojo) }\end{array}$ & .09 & .05 & .10 & .70 & .07 & .02 & -.18 & .56 \\
\hline $\begin{array}{l}\text { I believe that sacrificing myself for others } \\
\text { makes you a better person (Creo que } \\
\text { sacrificarse por otros te hace una major } \\
\text { persona). }\end{array}$ & .04 & .23 & .46 & .50 & -.03 & .26 & .39 & .70 \\
\hline $\begin{array}{l}\text { I feel like a terrible person when I know } \\
\text { someone is upset or disappointed with me } \\
\text { (Yo me siento como una persona terrible } \\
\text { cuando sé que alguien esta molesto o } \\
\text { desilusionado conmigo). }\end{array}$ & .03 & .03 & .11 & .74 & .02 & .03 & .26 & .64 \\
\hline $\begin{array}{l}\text { I find it difficult to say "no" to people even } \\
\text { when it is "no" is what I should be saying } \\
\text { (Encuentro difícil decir "no" a la gente, aún } \\
\text { cuando se que decir "no" es lo que debería) }\end{array}$ & .17 & .05 & .18 & .13 & .61 & .28 & .18 & .56 \\
\hline $\begin{array}{l}\text { I have difficulty asserting myself to figures of } \\
\text { authority (Tengo dificultades para hacerme } \\
\text { valer ante personas de autoridad.) }\end{array}$ & .10 & .25 & .29 & .24 & .58 & .04 & .09 & .56 \\
\hline $\begin{array}{l}\text { I feel guilty when I ask others to do things } \\
\text { for me (Me siento culpable cuando le pido a } \\
\text { otros que hagan cosas por mí.) }\end{array}$ & .34 & .02 & -.15 & .01 & .66 & .07 & -.23 & .64 \\
\hline $\begin{array}{l}\text { I often put myself down in relation to figures } \\
\text { of authority (A menudo me siento menos } \\
\text { ante las personas de autoridad) }\end{array}$ & .65 & .33 & -.21 & .49 & .53 & .13 & .09 & .70 \\
\hline $\begin{array}{l}\text { I try to make others happy at all cost (Trato } \\
\text { de hacer feliz a los otros a toda costa) }\end{array}$ & .11 & .02 & -.19 & .12 & .23 & .75 & -.05 & .68 \\
\hline $\begin{array}{l}\text { I find myself putting others' needs ahead } \\
\text { of my own (Considero primero las } \\
\text { necesidades e los otras personas antes de } \\
\text { las mías). }\end{array}$ & .14 & .02 & .15 & .05 & .05 & .66 & -.02 & .51 \\
\hline $\begin{array}{l}\text { I find myself putting family needs ahead } \\
\text { of my own (Considero primero las } \\
\text { necesidades de mí familia antes de las } \\
\text { mías) }\end{array}$ & .01 & .37 & .01 & .03 & -.10 & .54 & .39 & .60 \\
\hline $\begin{array}{l}\text { Making my partner happy makes me feel } \\
\text { better about.myself (Hacer feliz a mí pareja } \\
\text { me hace sentir bien conmigo misma) }\end{array}$ & .17 & .25 & .04 & .14 & .03 & .03 & .82 & .78 \\
\hline Eigenvalue & 2.1 & 2.1 & 2.0 & 1.8 & 1.6 & 1.6 & 1.5 & \\
\hline Percentage of variance explained & 11.1 & 10.4 & 10.3 & 9.0 & 8.2 & 7.3 & & \\
\hline
\end{tabular}


Table 4 - Factor loadings for Confirmatory Factor Analysis with Varimax Rotation of the Hispanic Stress InventoryImmigrant version $(H S I-I)(n=81)$

\begin{tabular}{|c|c|c|c|}
\hline Item & $\begin{array}{l}\text { Interfamilial } \\
\text { stressors }\end{array}$ & $\begin{array}{l}\text { Extrafamilial } \\
\text { stressors }\end{array}$ & Communality \\
\hline $\begin{array}{l}\text { Lack of English makes interactions difficult (Por no saber suficiente nglés ha sido difícil para mi } \\
\text { socializar con otros) }\end{array}$ & .61 & .03 & .38 \\
\hline $\begin{array}{l}\text { People expect me to work harder because I am Latino (Debido a que soy latina se ha esperado } \\
\text { que trabaje más rapido o duro) }\end{array}$ & .53 & .39 & .40 \\
\hline $\begin{array}{l}\text { I do not feel like I earn enough money to support my family or myself. (Mis ingresos no han sido } \\
\text { suficientes para mantener a mi familia o a mí misma) }\end{array}$ & .64 & .16 & .43 \\
\hline $\begin{array}{l}\text { Finding a job that I want has been difficult because I am Latino. Debido a que soy latina he tenido } \\
\text { dificultad para encontrar el tipo de trabajo que quiero) }\end{array}$ & .63 & .52 & .67 \\
\hline $\begin{array}{l}\text { Sometimes I feel as though others expect me to be lazy. (He tenido que ser cuidadosa con la } \\
\text { calidad de mi trabajo para que otros no piensen que soy una perezosa) }\end{array}$ & .70 & .31 & .59 \\
\hline $\begin{array}{l}\text { Because I am Latino, promotions or salary raises are hard to get (Debido a que soy latina, ha } \\
\text { sido dificil obtener ascensos o aumentos de salario) }\end{array}$ & .67 & .35 & .57 \\
\hline I have to accept low paying jobs. (Me he visto forzada a aceptar trabajos con salarios bajos) & .75 & .11 & .58 \\
\hline $\begin{array}{l}\text { I have felt pressured (or forced) to learn English.(Me he sentido presionada (o forzada) para } \\
\text { aprender inglés) }\end{array}$ & .67 & -.02 & .45 \\
\hline $\begin{array}{l}\text { I have thought that if I went to a social or government agency I would be deported (He pensado } \\
\text { que si voy a una agencia social o del gobierno sería deportada) }\end{array}$ & .57 & -.05 & .32 \\
\hline $\begin{array}{l}\text { My spouse and I disagree on how to bring up our children (Mi esposo y yo hemos tenido } \\
\text { desacuerdos acerca de como criar a nuestros hijos) }\end{array}$ & .05 & .75 & .56 \\
\hline $\begin{array}{l}\text { Because of my poor English, people treat me badly (Debido a mi mal inglés, la gente me ha } \\
\text { tratado mala) }\end{array}$ & .39 & .59 & .48 \\
\hline $\begin{array}{l}\text { My children do not respect my authority the way they should (Mis hijos(as) no respetan mi } \\
\text { autoridad en la forma que deberían) }\end{array}$ & -.02 & .77 & .59 \\
\hline $\begin{array}{l}\text { I have felt that my children's ideas about sexuality are too liberal (He sentido que las ideas de mis } \\
\text { hijos(as) acerca de la sexualidad son demasiado liberales) }\end{array}$ & .14 & .12 & .03 \\
\hline $\begin{array}{l}\text { There have been conflicts (or disagreements) among members of my family (Ha habido conflictos } \\
\text { o malos desentendidos entre miembros de mi familia) }\end{array}$ & .15 & .49 & .26 \\
\hline $\begin{array}{l}\text { There has been physical violence among members of my family (Ha habido violencia física entre } \\
\text { miembros de mi familia) }\end{array}$ & .09 & .55 & .31 \\
\hline $\begin{array}{l}\text { My children have talked about leaving home (Mis hijos(as) han hablado acerca de irse de la } \\
\text { casa) }\end{array}$ & -.20 & .49 & .28 \\
\hline $\begin{array}{l}\text { My children have received bad school reports (or bad grades) (Mis hijos(as) han recibido malas } \\
\text { calificaciones o reportes en la escuela) }\end{array}$ & .20 & .41 & .21 \\
\hline $\begin{array}{l}\text { I had serious arguments with family members (He tenido serios problemas con miembros de mi } \\
\text { familia) }\end{array}$ & .17 & .35 & .15 \\
\hline Eigenvalue & 5.2 & 2.0 & \\
\hline Percentage of variance explained & 28.9 & 11.4 & \\
\hline
\end{tabular}

Self-Efficacy and Exercise Habits Survey: The Likert scale was reduced to 3 anchors: 1) "I am sure I cannot"; 2) "Maybe I can" 3) "I am sure that I can". The revised Spanish version of the SEHS contained 15 items, with a possible range of 15-45. Mean score for the questionnaire was $37.5(\mathrm{SD}=4.81)$, with a range of 2845. The histogram plot of the data revealed skewness of -.22 and kurtosis of -1.0 . Although descriptive statistics were not calculated in the earlier sample, it appears there was less of a tendency for the women to choose extreme positive responses with the revised tool. All of the item -total subscale correlation coefficients ranged from .41 to .72. Cronbach's alpha for the SEHS was .81. KMO was .64 and Bartlett's test of Sphericity was statistically significant $(p<.001)$, both of which are acceptable ${ }^{(15)}$. CFA results are presented in Table 2 . Since only two factors had Eigenvalues over 1.0 and the Scree plot supported a two-component solution, CFA revealed the same twofactor solution identified in the English version ${ }^{(10)}$. Internal consistency for each of the two subscales, "Making time for exercise" and "Resisting relapse" was satisfactory at .75. These two factors accounted for $42.2 \%$ of the total variance.

Latina Values Scale Revised: Twenty-three of the twenty-eight items in the LVSR were retained and tested. The five items omitted were either of a sexual nature and not relevant to this study or were considered redundant. The five-point Likert scale used in the original LVSR was reduced to 3 anchors: 1) "I disagree"; 2) "Not sure" and 3) "I agree". The 5 anchors used in the original LVSR 
Conflict scale were reduced to 3 choices: 1) "Never"; 2) "Sometimes" and 3) "Always". Possible total score ranged from 23-69. Mean score on the LVSR was 45 ( $S D=7.23)$ with a range of 33-69. The histogram plot demonstrated a slight negative skew (-.28) and kurtosis of -.78 , suggesting that subjects did not tend to adhere to the extreme response style. Cronbach's alpha for the LVSR was acceptable at .74. Two items had item to subscale correlations less than the acceptable level of .40. These were: "I often put myself down in relation to men/ A menudo me sentido inferior en comparación a los hombres" and "I find myself believing that criticism is caused by my faults/ Creo que los conflictos y problemas son mi culpa." Based upon informal discussion with a subset of the women, the first question should have been omitted in this study as it was related to the other sexually-themed items. For the second question, the women felt the wording of the Spanish version of the question was confusing and evoked a different type of response than was intended by the English version. As a result, both items were subsequently excluded from analysis for this study. The KMO was .50 , indicating minimally acceptable sample size ${ }^{(16)}$ and Bartlett's Test of Sphericity was statistically significant $(p<.001)$. CFA supported the seven-factor model, which accounted for $66.5 \%$ of the variance. Internal consistency for each of the subscales $>.70$. Results of the CFA are presented in Table 3.

Hispanic Stress Inventory: The first half of each two-stage question pertaining to sources of immigrationrelated stress was not altered. The five-point Likert scale used in the second half of each question was reduced to three anchors: 1) "Not at all worried"; 2) "A little worried" and 3) "Very worried". Mean score for the main scale was $4.06(\mathrm{SD}=3.95)$, indicating that most of the subjects reported few instances of immigration-related stress. Potential range of scores for the second half of the revised tool was $0-54$. Mean score for the second half of the questions was $7.79(\mathrm{SD}=9.41)$ with a range of 0 -36. In the revised version, there were less than five percent of missing values. Item to subscale correlation coefficients were acceptable, ranging from .41 to .77. Cronbach's alpha for the entire tool was .74. KMO was .67 and Bartlett's Test of Sphericity was $p<.001$. Since only two factors had Eigenvalues over 1.0, CFA supported the two-factor model(13) of Interfamilial and Extrafamilial stressors. Internal consistency for the two subscales was .72 and .76 respectively. These two factors accounted for $40.3 \%$ of the total variance. A scree plot confirmed the two-factor solution. One item," I have felt that my children's ideas about sexuality are too liberal" did not load well on to either scale, probably because of the young age of the parents. The results are presented in Table 4. The item was added to the adapted tool, "I think that if I would go to a social service or government agency, I would be deported", exhibited an item to subscale correlation coefficient of .42. The internal consistency of the Extrafamiliar subscale remained the same whether or not the item was included, suggesting that it was a good fit in the subscale.

\section{Discussion}

The results support earlier studies that indicate the use of Likert scales among immigrant Latinos is often problematic. This is true even when the instruments have been previously translated into Spanish and have demonstrated adequate validity and reliability among Spanish speakers in the US. This study demonstrated that adapted Spanish language tools can be used successfully among groups of low-literacy immigrants who are unfamiliar with the research process. The adaptations appeared to improve the readability of the tools, resulting in a greater response rate, less missing data and a diminished trend toward extreme responses.

Although condensing the number of Likert anchors from five to three seemed to solve some of the subjects ambiguities, it also lowered the variability of the responses. In the CFA process, the isolated factors explained only 40 $65 \%$ of the total variance. Although identifying enough factors to account for $80-90 \%$ of the variance is desirable, this criterion could be as low as $50 \%$ when the goal is to explain variance with as few factors as possible ${ }^{(17)}$. Given that the CFA of each of the three instruments confirmed the original factor structure, this lends support for the format of the adapted tools. The issue of the optimum number of anchors in a Likert scale is a controversial one. Five to seven anchors are often considered ideal to assure a thorough representation of responses, but three points may be sufficient if the emphasis is on group rather than individual data. In this study, using more points than the subjects could understand might have resulted in increased variability, but not necessarily increased validity or reliability. Another potential issue is the loss of variability when the three-point Likert scale is used in a pre-test/ post-test format. When the ability to capture change is necessary, a larger number of anchors and subjects may be needed to be thoroughly briefed before data collection begins. It is notable that the subjects had little difficulty completing other Spanish language tools (e.g. the Center for Epidemiologic Studies Depression Scale (CES-D)) using multiple response scales when the choices were more quantifiable. This same format could be implemented in the design of new instruments to 
measure physical activity concepts. Rather than asking how confident the subject is about getting up early to exercise, the question could be worded, "How many times/ week do you feel that you could get up early to exercise?" In this case, the responses would be based on the number of days/week (e.g. 0, 1-2, 3-4. 5-6, 7). Such an approach would improve clarity and conceivably preserve response variability. While the women in this study had a mean nine years of education, $21 \%$ only completed the sixth grade. Since conversational literacy in a language is likely to be greater than familiarity with research terminology, it is not surprising that many of the subjects in Phase 1 struggled to complete the tools. Researchers who work with immigrant populations should take into account that subjects are not likely to be "research literate", so additional time and attention is needed for data collection instructions. One limitation of Phase 3 of the study was the small sample size. KMO values for two of the three instruments suggest the sample size was likely adequate. If there are four or more variables with loadings above .60 , the pattern may be interpreted whatever the sample size used and when communalities are high $(>60)$, sample sizes well below 100 will still be adequate. Repeated CFA of the instruments with larger sample sizes is advisable.

\section{Conclusion}

Adaptation of existing research tools remains a significant instrumentation challenge for researchers who work with immigrant Latinos. Given the growing diversity in the US population, nurse researchers need to consider a variety of culturally appropriate methods to encourage participation in research studies by low-literacy immigrant populations. Transnational collaborations among nurse researchers committed to the health of Latin American immigrants may be one approach to identify such culturally appropriate methods.

\section{References}

1. US Census Bureau, Population Division. Annual Estimates of the Resident Population by Sex, Race, and Hispanic Origin for the United States: April 1, 2000 to July 1, 2009; 2010. Retrieved June 15, 2010, from http://http://www.census.gov/popest/national/asrh/ NC-EST2009-srh.html.

2. Flaskerud, JH. Is the Likert scale format culturally biased? Nurs Res. 1988;37(3):185-6.

3. Bernal H, Wooley S, Schensul, JJ. Methodology corner: the challenge of using Likert-type scales with low-income ethnic populations. Nurs Res. 1997;46(3):170-81.

4. Lange JW. Methodological concerns for non-Hispanic investigators conducting research with Hispanic
Americans. Res Nurs Health. 2002;25:411-9.

5. McQuiston C, Larson K, Parrado, EA, Flaskerud, JH. AIDS knowledge and measurement considerations with unacculturated Latinos. West J Nurs Res. 2002;24(4):354-72.

6. Marin G, Triandis H C, Betacourt H, Kashima, Y. Ethnic affirmation versus social desirability: Explaining discrepancies in bilinguals' responses to a questionnaire. J Cross Cult Psychol. 1983; 14:173-86.

7. Marin G, Gamba RJ, Marin BV. Extreme response style and acquiescence among Hispanic Americans. J Cross Cult Psychol.1992;23:498-509.

8. Aday LA, Chiu GY, Andersen, R. Methodological issues in health care surveys of the Spanish heritage population. Am J Publ Health. 1980;70:367-74.

9. Cavazos-Rehg P, Zayas L, Spitznagel E. Legal status, emotional well-being and subjective health status of Latino immigrants. J Natl Med Assoc. 2007;99(10):1126-31.

10. Sallis JF, Pinski PB, Grossman RM, Patterson TI, Nader PR. The development of self-efficacy scales for health-related diet and exercise behaviors. Health Educ Res. 1988;3:283-92.

11. Marano MR. The creation of the Latina Values Scale: An analysis of marianismo's effects on Latina women attending college. Dissertation Abstracts International: Section A. Humanities and Social Sciences; 2004.

12. Cavazos-Rehg PA, Zayas LH, Walker MS, Fisher EB. Evaluating an abbreviated version of the Hispanic Stress Inventory for immigrants. Hispanic J Behav Sci. 2006;28(4):498-515.

13. McArthur LH, Holbert D, Pena,M. Development and application of rapid assessment diet and physical activity indexes, which suggest high consumption of energydense foods and inadequate exercise among adolescents from six Latin American cities: a pilot study. Nutr Res. 2008;28(9):590-9.

14. Melendez FA. (2004). The Latina Value Scale Revised: a cross-sectional analysis of marianismo in Latino women. Dissertation Abstracts International: Section A. Humanities and Social Sciences; 2008.

15. Tabachnick BG, Fidell LS. Using multivariate statistics. 5th ed. Boston, MA: Allyn and Bacon; 2007.

16. Kaiser HF, Rice J. Little Jiffy, Mark IV. Educational and Psychological Measurement. Educ Psychol Meas.1974;34:111-7.

17. Stevens JP. Applied multivariate statistics for the social sciences. 4th ed. Mahwah, NJ: Lawrence Erlbaum; 2002.

Received: Jan. $18^{\text {th }} 2011$ Accepted: Ago. 15 th 2011 